JURNAL WAWASAN

YURIDIKA

Vol. 4 | No. 1 | Maret 2020 | Halaman : 31-46

Nationally Accredited Journal Decree No. 36/E/KPT/2019, Dated 13rd December 2019

http://ejournal.sthb.ac.id/index.php/jwy

\title{
Transformasi Akad Perbankan Syariah dalam Pembentukan Hukum Perikatan Nasional
}

\author{
Asep Rozali ${ }^{1}$ \\ ${ }^{1}$ Sekolah Tinggi Hukum Bandung, Jawa Barat, Indonesia \\ $\triangle$ Corresponding Author: ilazorpesa@gmail.com
}

Info Artikel:

DOI: $10.25072 /$ jwy.v4i1.320

Diterima: 27 Desember 2019

I Disetujui: 23 Maret 2020

|Dipublikasikan: 31 Maret 2020

Kata Kunci:

Akad; Hukum Perikatan;

Transformasi.

\begin{abstract}
Abstrak
Penelitian ini bertujuan untuk mengungkap karakteristik akad produk perbankan Syariah sehubungan dengan pembentukan hukum perikatan nasional. Narasi deskriptif dari jenis penelitian hukum normatif terhadap data sekunder berupa bahan hukum primer, sekunder, dan tersier yang diperoleh melalui studi kepustakaan dan studi dokumen, dengan pendekatan perundang-undangan dan pendekatan konseptual, dianalisis secara kualitatif dengan teori transformasi cybernetics sistem paradigmatik. Hasil penelitian menunjukkan transformasi akadakad produk perbankan Syariah mempunyai karakteristik bersifat khusus, yakni berupa pemenuhan prinsip Syariah, rukun dan syarat, menghindari riba, maisir, gharar, dan zhalim yang dapat dijadikan sebagai suatu konsep dalam pembentukan hukum perikatan nasional.
\end{abstract}

\section{Abstract}

This study aims to reveal the characteristics of Sharia banking product contracts in connection

Keywords:

Contract;

Law of Obligations;

Transformation. with the establishment of national contract law. Descriptive narrative of the type of normative legal research on secondary data in the form of primary, secondary and tertiary legal materials obtained through library studies and document studies, with the legislative approach and conceptual approach, analyzed qualitatively with the Transformation of Cybernetics System Paradigmatic Theory. The results of the study show that the transformation of Islamic banking product contracts has special characteristics and can be used as a concept in the formation of national engagement law. 


\section{A. PENDAHULUAN}

Historisitas hukum perikatan di Indonesia bermula dari diberlakukannya Burgerlijk Wetboek (BW) melalui penerapan asas concordantie oleh pemerintah kolonial Belanda terhadap negara jajahannya sekitar tahun 1848 (Burgerlijk Wetboek berlaku di Belanda mulai tahun 1838). Keadaan demikian berlanjut selama satu setengah abad, bahkan masih berlangsung hingga dewasa ini, padahal Indonesia telah memproklamirkan kemerdekaan pada 17 Agustus 1945, sehingga sejatinya asas concordantie sebagai "alat" yang memaksakan pemberlakuan BW, gugur dengan sendirinya.

BW yang merupakan kodifikasi, dalam kajian para pakar menunjukkan perbedaan atau distingsi dari segi sistematikanya. Berdasarkan sistematika undang-undang, BW terdiri atas 4 (empat) buku, yakni Buku I tentang Orang, Buku II tentang Kebendaan, Buku III tentang Perikatan, dan Buku IV tentang Pembuktian dan Daluarsa. Sedangkan ilmu pengetahuan (hukum), juga membagi menjadi 4 (empat) bidang yang terdiri atas tentang Orang, tentang Keluarga, tentang Kekayaan, dan tentang Waris. ${ }^{1}$ Distingsi di atas memunculkan implikasi terhadap kedudukan dan eksistensi BW, yakni
BW sebagai kitab undang-undang yang bersifat positivistik legalistik dengan sifat sanksinya yang melekat sehingga harus diikuti, dan BW sebagai kitab hukum yang berfungsi tidak sebagai hukum positif tetapi sebagai pedoman.

Adanya distingsi demikian, bagi peneliti hukum perdata menjadi objek yang menarik untuk diteliti. Salah satu yangmenarikuntukditelitiadalah perihal perikatan sebagai akibat dari perjanjian, tetapi ketentuannya tidak tercantum dalam Buku III tentang Perikatan. Dalam Buku III tersebut, pada bagian ke satu yang berisi ketentuan umum tidak satu pasal pun menyebutkan pengertian dari perikatan. Ketentuan umum tersebut hanya mengatur perihal yang disebut sebagai sumber hukum perikatan, yakni yang tercantum dalam Pasal 1233 BW dan objek perikatan dalam Pasal 1234 BW. Rumusan lengkap Pasal 1233 BW menentukan:

"Tiap-tiap perikatan dilahirkan baik karena persetujuan, baik karena undang-undang"

Sedangkan rumusan lengkap Pasal 1234 menentukan:

“Tiap-tiap perikatan adalah untuk memberikan sesuatu, untuk berbuat sesuatu atau untuk tidak berbuat sesuatu"

C.S.T. Kansil, Pengantar Ilmu Hukum Dan Tata Hukum Indonesia, Cet. Ke.7 (Jakarta: Balai Putaka, 1986), hlm. 214. 
Adapun pengertian perikatan pada umumnya dijelaskan sebagai suatu hubungan hukum di dalam bidang hukum harta kekayaan antara satu orang atau lebih yang saling mengikatkan dengan satu orang atau lebih untuk melaksanakan suatu prestasi. Unsur hubungan hukum merupakan sesuatu yang abstrak tetapi akibatnya diatur oleh hukum. Unsur hukum harta kekayaan merupakan hak-hak dan kewajiban yang berasal dari Buku II dan Buku III. Unsur orang, yakni debitur yang berkewajiban dan kreditur yang berhak, sedangkan unsur prestasi merupakan objek dari perikatannya.

Mencermati rumusan ketentuan Pasal 1233 BW yang dimaknai sebagai sumber perikatan dan korelasinya dengan penjelasan perikatan di atas, selain undang-undang, juga persetujuan (dibaca: perjanjian) sebagai suatu fakta mengakibatkan lahirnya perikatan sebagai suatu hubungan. Dalam Buku III BW, terdapat 14 perjanjian yang diatur dan dikategorikan perjanjian bernama. Sehingga dalam proposisi lain dapat dinyatakan, perjanjian bernama dalam Buku III BW merupakan fakta hukum yang menunjukkan hubungan hukum yang menimbulkan akibat hukum, yakni perikatan.

Secara fragmentaris, terdapat perjanjian yang diatur oleh peraturan lain di samping Buku III BW. Peraturan lain dimaksud, antara lain UndangUndang Nomor 21 Tahun 2008 tentang Perbankan Syariah (UUPS 2008) yang menggunakan prinsip Syariah sebagai landasan operasionalnya. Legislasi perbankan Syariah ini lahir setelah Bank Muamalat Indonesia berpraktik, operasionalisasinya bertujuan untuk memfasilitasi masyarakat yang menganggap bunga termasuk riba.

Berdasarkan hal itu, maka atas dukungan dan dorongan masyarakat yang menghendaki adanya pemisahan agar undang-undang perbankan Syariah yang akan dibentuk, dipisahkan dari undang-undang perbankan yang lebih dominan mengatur bank konvensional. Inisiatif pembuatan Rancangan UndangUndang Perbankan Syariah (RUU Perbankan Syariah) yang dilakukan oleh Dewan Perwakilan Rakyat pada tahun 2005 direspon dengan cepat oleh beberapa lembaga dengan mengajukan draf RUU Perbankan Syariah, antara lain Bank Indonesia mengajukan draf RUU Perbankan Syariah yang terdiri atas 16 bab dan 72 pasal, Asosiasi Bank Syariah Indonesia (Asbisindo) mengajukan draf RUU Perbankan Syariah yang terdiri atas 10 bab dan 49 pasal, serta Ikatan Cendekiawan Muslim Indonesia (ICMI) mengajukan draf RUU Perbankan Syariah yang terdiri atas 12 bab dan 66 pasal. $^{2}$

\footnotetext{
2 Andrew Shandy Utama, "Sejarah dan Perkembangan Regulasi Mengenai Perbankan Syariah Dalam Sistem Hukum Nasional," Jurnal Wawasan Yuridika Vol. 2 Nomor 2 (September 2018): hlm. 195.
} 
Penerapan prinsip Syariah ini dalam rangka mengakomodasi dimensi agama yang tidak terdapat dalam sistem hukum perbankan sebelumnya yang bersifat konvensional dan dominan diatur oleh BW. Keadaan demikian bukan saja terjadi di Indonesia yang mayoritas menganut Islam sebagai agamanya, juga terjadi di beberapa negara muslim setelah terlepas dari kolonisasi/penjajahan. Hal ini diungkapkan oleh Rihab Grassa dan Kaouthar Gazdar, bahwa:

"After colonization, most Muslim countries adopted the legal systems of the colonizing countries (Common Law or Civil Law) whilst keeping some legislative instructions from the Shari'a Law. Generally, these adopted legal systems do not reflect the Islamic culture and the Islamic ideology. That is why, for a long time, the lack of strong legal infrastructure institutions in Muslim countries was considered to be a huge challenge for the development and the growth of Islamic finance". 3

\section{UUPS 2008 berupaya untuk} merealisasikan atau setidaknya merefleksi kaidah-kaidah fikih sebagai nilai-nilai pokok dalam muamalah yang telah disepakati oleh para ahli hukum Islam. Terkait hal tersebut, berdasarkan penelitian terdahulu, dalam UUPS 2008 terkonfigurasi kaidah fikih secara tersirat dan tersurat, khususnya kaidah fikih yang dikemukakan Izzudin bin Abd As Salam. ${ }^{4}$

Pasca-digulirkannya UUPS 2008, setidaknya terdapat implikasi terhadap dua hal. Pertama terhadap hukum perbankan nasional dengan dipraktikannya dual banking system, yakni suatu keadaan dalam satu negara mempraktikan dua sistem hukum perbankan yang berbeda secara bersamaan, dalam hal ini sistem perbankan konvensional dan sistem perbankan Syariah. Kedua, terhadap hukum perikatan nasional, yakni lahirnya akad-akad produk perbankan Syariah.

Akad produk perbankan Syariah berdasarkan prinsip Syariah, lahir dari transaksi-transaksi, yakni: 1) Tidak mengandung riba; 2) Bertujuan untuk memiliki barang dengan cara jual beli (murabahah); 3) Bertujuan untuk mendapatkan jasa dengan cara sewa (ijarah); 4) Bertujuan untuk mendapatkan modal kerja dengan cara bagi hasil (mudharabah); dan 5) Deposito, Tabungan, Giro dengan imbalan bagi

3 Rihab Grassa dan Kaouthar Gazdar, "Law and Islamic Finance: How Legal Origins Affect Islamic Finance Development?," Borsa Istanbul Review 14, No. 3 (September 2014): hlm. 160., https://doi. org/10.1016/j.bir.2014.05.001.

4 Asep Rozali, "Configuration of Act Number 21 of 2008 Based on Act Number 21 of 2011 and Qaidah Fiqh" ( $3^{\text {rd }}$ International Conference on Islamic Law In Indonesia "Reviving and Strenghtening Islamic Law as a Living Law Within World's Legal System," Universitas Mulawarman, Samarinda: Publishing Agency Faculty of Law, Indonesia University, 4-6 September), hlm. 132. 
hasil (mudharabah), dan transaksi titipan (wadiah). ${ }^{5}$

Penelitian ini berobjek pada produk perbankan Syariah yang berasal dari kegiatan usaha Bank Syariah yang dituangkan dalam suatu akad berdasarkan UUPS 2008. Jenis dan kegiatan usaha dimaksud dirumuskan dalam Pasal 19 sampai dengan Pasal 21. Setiap jenis dan kegiatan usaha dalam rumusannya diawali dengan kata akad, sehingga dengan demikian dapat dikatakan bahwa setiap jenis dan kegiatan usaha Bank Syariah menghendaki dan mensyaratkan adanya akad. Berdasarkan hal tersebut, maka tidak berlebihan apabila disebutkan bahwa jenis dan kegiatan usaha tersebut sejatinya memuat ketentuan-ketentuan hukum aplikatif operasional yang terkategori sebagai hukum perikatan Syariah yang berasal dari Al Quran, hadits, dan ijtihad.

Pengkajian akad produk perbankan Syariah dalam hubungannya dengan pembentukan hukum perikatan nasional penting dilakukan dan sangat relevan. Relevansi pengkajian akad produk perbankan Syariah sehubungan dengan pembentukan hukum perikatan nasional didasarkan pada pemikiran bahwa akad produk perbankan Syariah merupakan aspek yang fundamental di samping hukum adat dan hukum barat. Oleh karena itu berdasarkan eksplanasi yang telah dideskripsikan di atas, penelitian ini bertujuan untuk mengungkapkan karakteristik akad produk perbankan Syariah sehubungan dengan pembentukan hukum perikatan nasional berdasarkan teori transformasi sistem cybernetics paradigma hukum.

\section{B. METODE PENELITIAN}

Secara deskriptif, narasi dari penelitian yuridis normatif terhadap data sekunder berupa bahan hukum primer, sekunder, dan tersier yang diperoleh melalui studi pustaka dan studi dokumen, serta dengan pendekatan perundang-undangan dan pendekatan konseptual, analisisnya dilakukan secara kualitatif.

\section{HASIL DAN PEMBAHASAN}

Dalam khazanah hukum Islam, secara etimologi, frasa kata akad berasal dari bahasa Arab, yakni aqad yang artinya adalah janji sebagaimana tercantum, antara lain dalam Al Qur'an Surat $A l$ Maidah ayat 1 , "Hai orang-orang yang beriman tepatilah janji-janjimu." Kamus Besar Bahasa Indonesia mengartikan, akad sebagai janji; perjanjian dan

Santoso dan Suhadi, "Periodesasi Perkembangan Hukum Perbankan Syariah di Indonesia," Jurnal YUDISIA Vol. 6. No. 1 (2015): hlm. 132. 
kontrak. ${ }^{6}$ Salah satu istilah dalam Al Qur'an yang berhubungan dengan al aqdu dan al $a h d u^{7}$, berupa perjanjian tertulis yang memuat ijab (penawaran), dan qabul (penerimaan). ${ }^{8}$ Selain berdasarkan bahasa dan istilah, akad didasarkan pada kehendak manusia merupakan tasharruf. Tasharruf, yakni segala sesuatu yang keluar dari seorang manusia dengan kehendaknya dan syara' menetapkan beberapa hak. Tasharruf terbentuk secara fili dan qauli. Tasharruf fili adalah usaha manusia dengan tenaga dan badannya, selain lidah. Sedangkan Tasharruf qauli adalah sesuatu yang keluar dari lidah manusia yang dapat berupa aqdi dan bukan aqdi. Tasharruf qauli aqdi dibentuk dari dua ucapan kedua belah pihak yang saling bertalian, seperti jual beli, dan sewa menyewa. Tasharruf qauli bukan aqdi dibentuk karena pernyataan yang melahirkan atau menghilangkan suatu hak, seperti waqaf, talaq. Dapat pula tidak berupa pernyataan, tetapi mewujudkan tuntutan. 9 Dalam Kompilasi Hukum Ekonomi Syariah (KHES), Buku II tentang Akad Bab I Ketentuan Umum Pasal 20 angka 1 dijelaskan, Akad adalah kesepakatan dalam suatu perjanjian antara dua pihak atau lebih untuk melakukan dan atau tidak melakukan perbuatan hukum tertentu. ${ }^{10}$

Praktik akad telah lama dikenal oleh masyarakat manusia, akad muncul sesudah adanya ihraz al mubahat atau penguasaan terhadap benda yang belum dimiliki oleh orang lain. ${ }^{11} \mathrm{Hal}$ ini karena akad baru dapat dilakukan apabila ada sesuatu hal yang dapat diikatkan dengan orang lain. Orang akan membutuhkan suatu akad, ketika ada suatu hal (benda/ milik) yang berharga dan setiap orang ingin memilikinya. ${ }^{12}$

Bentuk tertulis suatu akad dalam Al Qur'an telah diperintahkan sebagaimana tercantum pada surat Al Baqarah ayat 282:

"Wahai orang-orang yang beriman! Apabila kamu melakukan utangpiutanguntukwaktuyang ditentukan hendaklah kamu menuliskannya. Dan hendaklah seorang penulis di antara kamu menuliskannya dengan benar. Janganlah penulis menolak untuk menuliskannya sebagaimana Allah telah mengajarkan kepadanya, hendaklah dia menuliskannya..."

\footnotetext{
6 Kamus Besar Bahasa Indonesia, http://www.kbbi.web.id diakses 21 November 2019.

7 Gemala Dewi, Wirdyaningsih, dan Yeni Salma Barlianti, Hukum Perikatan Islam di Indonesia (Jakarta: Badan Penerbit FH UI, 2007), hlm. 45.

8 Irma Devita, Kiat-kiat Cerdas, Mudah, dan Bijak Memahami Masalah Akad Syariah (Bandung: Mizan Pustaka, 2011), hlm. 2.

9 Hendi Suhendi, Fikih Muamalah (Jakarta: Raja Grafindo, 2008), hlm. 43.

10 "Peraturan Mahkamah Agung tentang Kompilasi Hukum Ekonomi Syariah," Pub. L. No. Peraturan Mahkamah Agung RI Nomor 2 Tahun 2008.

11 Nasrun Harun, Figh Muamalah (Jakarta: Gaya Media Pratama, 2011), hlm. 32.

12 Rahmawati, "Dinamika Akad Dalam Transaksi Ekonomi Syariah," Jurnal Al Iqtishad Vol. III No. 1 (Januari 2019): hlm. 25.
} 
Apabiladiperhatikandaripenjelasanpenjelasan terkait akad di atas, baik dalam Al Qur'an, UUPS 2008, dan konsep dari beberapa ahli sebagai suatu janji atau perjanjian menghendaki bahwa akad harus tertulis atau dituliskan.

Dalam hukum Islam, keabsahan akad digantungkan pada terpenuhinya rukun dan syarat. Oleh para ahli fikih dijelaskan, rukun merupakan sesuatu yang keberadaannya bergantung kepada sesuatu lainnya yang terdiri atas orang yang berakad, objek akad, ijab qabul, dan tujuannya. ${ }^{13}$ Sedangkan berkaitan dengan syarat, para ahli hukum Islam menjelaskan beberapa hal terkait syarat dari akad, yakni terjadinya atau syuruth al in'igad, sahnya atau syuruth al shihah, pelaksanaan atau syuruth an nafadz, dan kepastian atau syuruth al luzum. ${ }^{14}$ Berelasi dengan penjelasan dimaksud, dalam KHES rukun dan syarat akad diatur pada Buku II Bab III di bawah judul Rukun, Syarat, Kategori Hukum, 'Aib, Akibat dan Penafsiran Akad yang terdiri atas 4 pasal, yakni Pasal 22, Pasal 23, Pasal 24 dan Pasal 25.

Pasal 22 menentukan:

"Rukun dan Syarat terdiri atas:

a. Pihak-pihak yang berakad;

b. Objek akad;

c. Tujuan pokok akad; dan

d. Kesepakatan."
Penjelasan dari kandungan rukun dan syarat dimaksud dirumuskan masing-masing, dalam Pasal 23:

"Pihak-pihak yang berakad adalah orang-orang, persekutuan, atau badan usaha yang memiliki kecakapan dalam melakukan perbuatan hukum".

Pasal 24:

“Objek akad adalah amwal atau jasa yang dihalalkan yang dibutuhkan oleh masing-masing pihak"

Pasal 25:

"Akad bertujuan untuk memenuhi kebutuhanhidup dan pengembangan usaha masing-masing pihak yang mengadakan akad"

Suatu akad yang memenuhi ketentuan-ketentuan di atas dikatakan sebagai akad yang shahih, mengikat para pihak. Sedangkan yang tidak memenuhi ketentuan rukun dan syarat dikatakan sebagai akad yang tidak shahih, sehingga tidak berlaku dan tidak mengikat para. Terkait dengan akad, menurut Hasbi al Shiddiqie dalam Al Quran dan Hadis terdapat beberapa akad bernama atau al Uqud al Musamma, yaitu Bai Kafalah, Bai Hawalah, Bai Rahn, al Wafa, Wadiah, al Iarah, Hibah, Aqd al qisamah, Syirkah, Mudharabah, Muzaarah, Musaqah,

13 Rozalinda, Fikih Ekonomi Syariah (Jakarta: Rajagrafindo Persada, 2016), hlm. 47.

14 Faturrahman Djamil, Penerapan Hukum Perjanjian dalam Transaksi di Lembaga Keuangan Syariah (Jakarta: Sinar Grafika, 2012), hlm. 40. 
Wakalah, Shulh, Tahkim, Mukharaj, Qardh, Aqdulumari, Aqdulmuqalah/wala', Aqduliqalah, Zawaj, Aqdulwashiyyah, dan Aqdulisha. ${ }^{15}$

Di samping syarat dan rukun yang harus dipenuhi, dalam, terdapat beberapa asas hukum yang memengaruhi status akad. Pengaruh dimaksud bahwa ketika asas tidak terpenuhi dalam suatu akad, maka menjadikan tidak sahnya akad yang dibuat. Asas-asas hukum Islam yang dimaksud sebagaimana dikemukakan oleh Fathurrahman Djamil yang dikutip dari berbagai sumber, yaitu sebagai berikut:

1. Kebebasan/Hurriyah (QS :Al Baqarah (2): 256, Al Maidah (5): 1, Al Hijr (15): 29, Ar Rum (30):30, At Tin (95):4, Al Ahzab (33):72, dan Hadis Riwayat Tirmidzi dari 'Amir bin 'Auf: Perdamaian dapat dilakukan kaum muslimin, kecuali perdamaian yang mengharamkan yang halal atau menghalalkan yang haram, dan kaum muslimin terikat dengan syarat syarat mereka, kecuali syarat syarat yang mengharamkan yang halal atau menghalalkan yang haram;

2. Persamaan atau Kesetaraan/Al Musawah QS Al Hujurat 49: 3. Asas ini sering disebut asas keseimbangan para pihak, walaupun faktanya terdapat keadaan seperti standard contract. Terkait ini, hukum Islam menganggap bahwa standard contract sifatnya tetap hanya merupakan usulan atau penyajian, dan bukan bersifat final;

3. Keadilan/Al Adalah (QS Al Araf (7): 29, An Nahl (16): 90, Asy Syura (42): 15, Al Maidah (5): 1, 8-9, Al Baqarah (2): 177, Al Mu'minun (23): 8;

4. Kerelaan/Konsensualisme/Al Ridhaiyyah QS An Nisa 4:29. Namun, adakalanya ketentuan perundangundangan menetapkan suatu formalitas, seperti berbentuk akta notaris;

5. Kejujuran dan Kebenaran/Ash Shidq QS Ali Imran (3): 95, Al Ahzab 33: 70;

6. Kemanfaatan/Al Manfaat (QS Al Baqarah (2): 168, An Nahl (16): 114; dan

7. Tertulis/Al Kitabah QS Al Baqarah(2): 282-283. ${ }^{16}$

Pemenuhan rukun, syarat dan prinsip Syariah merupakan suatu hal penting yang berkaitan dengan kredibilitas Bank Syariah. Sebagaimana dikemukakan oleh Neneng Nurhasanah, bahwa kepercayaan stakeholders terhadap lembaga keuangan Syariah yang kredibel akan menstimulasi tumbuh

\footnotetext{
15 Hasbi al Shiddiqie, Pengantar Fikih Muamalah (Jakarta: Bulan Bintang, 1990), hlm. 93-108.

16 Fathurrahman Djamil, op.cit., hlm. 14-26.
} 
dan berkembangnya lembaga keuangan Syariah lebih cepat lagi ${ }^{17}$.

Demikian pula berkaitan dengan rambu-rambu yang dilarang menurut syariah, berdasarkan Penjelasan Pasal 2 ayat (3) Peraturan Bank Indonesia (PBI) Nomor 7/46/PBI/2005 tentang Akad Penghimpunan dan Penyaluran Dana bagi Bank yang Melaksanakan Kegiatan Usaha Berdasarkan Prinsip Syariah, dijelaskan hal-hal berikut ini. Gharar adalah transaksi yang mengandung tipuan dari salah satu pihak sehingga pihak yang lain dirugikan; Maysir adalah transaksi yang mengandung unsur perjudian, untung-untungan, atau spekulatif yang tinggi; Riba adalah transaksi dengan pengambilan tambahan, baik dalam transaksi jual-beli maupun pinjam-meminjam secara batil atau bertentangan dengan ajaran Islam; Zalim adalah tindakan atau perbuatan yang mengakibatkan kerugian dan penderitaan pihak lain; Risywah adalah suatu tindakan suap dalam bentuk uang, fasilitas, atau lainnya yang melanggar hukum; serta Barang haram dan maksiat adalah barang atau fasilitas yang dilarang dimanfaatkan ataupun digunakan yang berdasarkan pada hukum Islam. ${ }^{18}$ Sebagai perbandingan, unsur-unsur yang harus ada dalam sebuah akad atau kontrak saat ini, sebagaimana dikemukakan Afzalur Rahman, pertama harus ada penawaran dan persetujuan, kedua, memiliki maksud menciptakan hubungan kerja, ketiga, jelas tujuannya disertai adanya pengurus/pelaksana, keempat, mengetahui syarat-syarat dari pihak yang mengadakan akad, kelima, adanya perizinan yang sah, keenam, tujuannya halal, dan ketujuh, adanya jangka waktu tertentu. ${ }^{19}$ Sedangkan dalam hukum perikatan, terkait unsurunsur yang harus ada dalam suatu perjanjian meliputi unsur essentialia, naturalia dan accidentalia.

Dalam UUPS 2008 Bab I Ketentuan Umum, pada Pasal 1 angka 13 dijelaskan: "Akad adalah kesepakatan tertulis antara Bank Syariah atau Unit Usaha Syariah dan pihak lain yang memuat adanya hak dan kewajiban bagi masing-masing pihak sesuai dengan Prinsip Syariah"

Akad sebagaimana dijelaskan tersebut bertalian erat dengan kegiatan usaha perbankan Syariah berupa produk dan jasa. Dalam Pasal 19 UUPS 2008, disebutkan kegiatan usaha Bank Syariah yang berbentuk Bank Umum Syariah atau

17 Neneng Nurhasanah, "Optimalisasi Peran Dewan Pengawas Syariah (DPS) di Lembaga Keuangan Syariah," Jurnal Syiar Hukum Vol. XIII, No. 3 (November, 2011), hlm. 221.

18 Trisandini Prasastinah Usanti, "Akad Baku Pada Pembiayaan Murabahah di Bank Syariah," Jurnal Perspektif Volume XIII, No. 1 (Januari 2013): hlm. 49.

19 Rahmawati, “Dinamika Akad Dalam Transaksi Ekonomi Syariah,” op.cit., hlm. 29. 
Unit Usaha Syariah dan Pasal 21 berupa kegiatan usaha bank pembiayaan rakyat Syariah. Berdasarkan dua ketentuan tersebut, usaha perbankan Syariah digolongkan berupa penghimpunan dan penyaluran dana, serta bidang jasa.

Penghimpunan dana (funding) adalah kegiatan penarikan, pengumpulan dana dari masyarakat. Produk penghimpunan ini berupa giro (wadiah dan mudharabah), tabungan (wadiah dan mudharabah), dan deposito (deposito mudharabah). Kegiatan ini hampir sama dengan yang dilakukan oleh bank konvensional. Produk penyaluran dana kepada masyarakat berupa pembiayaan didasarkan pada akad jual beli yang menghasilkan produk murabahah, salam dan istishna. Berdasarkan pada akad sewa-menyewa menghasilkan produk berupa ijarah dan ijarah muntahiya bittamilk (ijarah waiqtina) berdasarkan akad bagi hasil yang menghasilkan produk mudharabah, musyarakah, muzzaroah, dan musaqah dan berdasarkan pada akad pinjaman yang bersifat sosial berupa qardh dan qardh al-hasan. Terhadap akad-akad tersebut dan aplikasinya dalam produk perbankan dibagi menjadi 4 (empat) klasifikasi akad, yaitu berdasarkan prinsip jual beli, berdasarkan sewamenyewa, berdasarkan bagi hasil, dan akad pinjaman sosial. Ada pun produk perbankan Syariah di bidang jasa didasarkan pada akad-akad hawalah, kafalah, wakalah, gadai (rahn), dan sharf.

Berbeda dengan produk kegiatan usaha perbankan konvensional, tiap akad perbankan Syariah harus sesuai dengan prinsip Syariah atau prinsip hukum Islam berupa fatwa yang diformulasikan oleh Dewan Syariah Nasional Majelis Ulama Indonesia (DSN-MUI).

Berkaitan dengan hal tersebut, DSNMUI pertama kali mengeluarkan fatwa pada tahun 2000, yakni fatwa tentang Giro No. 01/DSN-MUI/IV/2000, fatwa tentang Tabungan No. 02/DSN-MUI/ IV/2000, fatwa tentang Deposito No. 03/DSN-MUI/IV/2000, fatwa tentang Murabahah No.04/DSN-MUI/IV/2000, fatwa tentang Jual Beli Salam No. 05/ DSN-MUI/IV/2000, fatwa tentang Jual Beli Istishna' No. 06/DSN-MUI/IV/2000, fatwa tentang Pembiayaan Mudharabah (Qiradh) No.07/DSN-MUI/IV/2000, fatwa tentang Pembiayaan Musyarakah No. 08/DSN-MUI/IV/2000, fatwa tentang Pembiayaan Ijarah No.09/DSN-MUI/ IV/2000, fatwa tentang Wakalah No. 10/DSN-MUI/IV/2000, fatwa tentang Kafalah No. 11/DSN-MUI/IV/2000, dan fatwa tentang Hawalah No. 12/ DSN-MUI/IV/2000. Mencermati tahun terbitnya fatwa, maka fatwa ini terlihat diperuntukan bagi Bank Muamalat dan beberapa Bank Perkreditan Rakyat Syariah yang telah berpraktik pada dekade 1990an. Kemudian pada tahun 2008 terbit fatwa tentang Musyarakah Mutanaqisah No. 73/DSN-MUI/XI/2008 dan tahun 2015 tentang Sertifikat Deposito Syariah N0.97/DSN-MUI/ XII/2005. Berdasarkan substansi yang dituangkan dalam fatwa-fatwa tersebut tidak secara eksplisit ditujukan pada akad. 
Fatwa yang secara eksplisit mencantumkan kata 'akad', terdapat pada fatwa tentang Konversi Akad Mudharabah No. 49/DSN-MUI/II/2005, fatwa tentang Akad Al Ijarah Akad Al Maushufah fi Al Dzimmah No.101/DSNMUI/X/2016, dan fatwa tentang Akad Al Maushufah fi Al Dzimmah untuk Produk Pembiayaan Pemilikan Rumah (indent) No.102/DSN-MUI/X/2016. Kemudian pada tahun 2017 berturut-turut diterbitkan fatwa Akad Jual Beli No.110/ DSN-MUI/IX/2017, fatwa tentang Akad Jual Beli Murabahah No.111/ DSN-MUI/IX/2017, fatwa tentang Akad Ijarah No.112/DSN-MUI/X/2017, fatwa tentang Akad Wakalahbil Urjah No.113/ DSN-MUI/X/2017, fatwa tentang Akad Syirkah No.114/DSN-MUI/X/2017, dan tentang Akad Mudharabah No.115/DSNMUI/X/2017.

Berdasarkan fatwa-fatwa sebagaimana disebutkan di atas, terlihat bahwa fatwa yang diterbitkan pada awal tahun 2000 substansinya sederhana, terdapat 3 sampai 4 diktum, sedangkan fatwa yang terbit setelah UUPS 2008, khususnya tahun 2017 substansinya lebih lengkap dan rinci, terdapat 6 sampai dengan 8 diktum. Diktum yang tercantum pada dasarnya bersifat mengatur untuk dikeluarkannya suatu akad perbankan
Syariah sesuai dengan kegiatan usahanya.

Keseluruhan fatwa DSN-MUI, ada yang murni hasil penggalian hukum (ijtihâd istinbâthî) dan ada yang mengadopsi prinsip-prinsip akad yang termuat dalam figh mu'âmalah. Proses adopsi akad-akad ke dalam fatwa DSNMUI yakni dalam rangka implementasi prinsip-prinsip akad (ijtihâd thatbîqî) ke dalam institusi keuangan/bisnis Syariah. Pengadopsian akad-akad mu'âmalah tersebut ada yang bersifat tunggal (al'aqd al-fardliyah) dan ada yang bersifat multi akad berupa perpaduan antara akad satu dengan lainnya namun tetap memerhatikan ketentuan batasanbatasan (hudûd wa dlawâbith) dalam syariah. $^{20}$

Sifat mengatur pada fatwa yang diterbitkan pada tahun 2000 berkaitan dengan ketentuan umum, rukun dan syarat, serta ketentuan lain yang berhubungan dengan hak dan kewajiban. Misalnya dalam pembiayaan mudharabah, terdapat ketentuan umum yang antara lain mengatur jangka waktu, jumlah dana, kriteria mudharib, dan biaya. Rukun dan syarat, antara lain memuat kecakapan hukum, pernyataan ijabqabul dari proses penawaran dan penerimaan, serta syarat keuntungan yang dibagikan.

20 Burhanuddin Susanto, "Tingkat Penggunaan Multi Akad Dalam Fatwa Dewan Syariah NasionalMajelis Ulama Indonesia," Jurnal al ahkam Volume 11, No. 1 (Juni, 2016): hlm. 204. 
Sifat mengatur pada fatwa yang terbit setelah berlakunya UUPS 2008, keadaannya lebih rinci. Misalnya pada fatwa akad mudharabah, substansinya mengatur tentang ketentuan umum terdiri atas 15 aturan, ketentuan hukum bentuk mudharabah terdiri atas 4 aturan, ketentuan shighat akad terdiri atas 3 aturan, ketentuan para pihak terdiri atas 4 aturan, ketentuan terkait ra'as al mal terdiri atas 7 aturan, ketentuan nisbah bagi hasil terdiri atas 6 aturan, ketentuan kegiatan usaha terdiri atas 5 aturan, ketentuan pembagian keuntungan dan kerugian terdiri atas 4 aturan, ketentuan aktivitas dan produk LKS terdiri atas 3 aturan, dan ketentuan penutup terdiri atas 3 aturan.

Kendati fatwa-fatwa tersebut bersifat mengatur, namun kedudukan fatwa tersebut berupa pendapat, nasihat ulama yang tidak mengikat. Oleh karena itu, agar mengikat substansi dari fatwa memerlukan suatu perumusan lebih lanjut dalam bentuk regulasi atau legislasi, ${ }^{21}$ dalam hal ini regulasi dari Bank Indonesia atau Otoritas Jasa Keuangan (OJK).
Apabila dikaji dengan teori transformasi sistem cybernetics paradigma hukum yang memuat beberapa komponen yang terdiri atas 1) Masyarakat hukum; 2) Budaya hukum; 3) Filsafat hukum; 4) Ilmu/ pendidikan hukum; 5) Konsep hukum; 6) Pembentukan hukum; 7) Bentuk hukum; 8) Penerapan hukum;9) Evaluasi hukum, dan 10) Masyarakat hukum², maka terkait akad-akad produk perbankan Syariah dapat dijelaskan berdasarkan komponen-komponen dari teori dimaksud sebagaimana dipaparkan di bawah ini.

Akad perbankan Syariah di Indonesia pada awalnya terdapat pada masyarakat hukum yang sederhana dengan budaya hukum yang dalam mengatur kehidupannya cenderung menggunakan hukum tidak tertulis, baik hukum adat maupun hukum Islam yang dikategorikan sebagai living law. Pada tahap ini, konsep awal akad perbankan Syariah dimunculkan melalui fatwa DSN-MUI sesuai dengan kegiatan usahanya seperti dicontohkan di atas. Fatwa ini dalam rangka memedomani Bank Muamalat, BPR Syariah, dan bank konvensional yang antara lain

21 M. Erfan Riadi, "Kedudukan Fatwa Ditinjau Dari Hukum Islam dan Hukum Positif (Analisis Yuridis Normatif)," Jurnal Ulumuddin Volume VI Tahun IV (Juni 2010): hlm. 476.

22 Penjelasan teori ini dapat dibaca dalam Lili Rasjidi dan Ida Bagus Wyasa Putra, Hukum Sebagai Sistem (Jakarta: Fikahati Aneska, 2012). 
menjalankan kegiatan usaha berbasis bagi hasil. Filosofi yang diusung dalam rangka memfasilitasi anggota masyarakat yang mengkategorikan bunga bank adalah riba.

Das Sein dari praktik perbankan Syariah kemudian menjadi topik yang menarik tidak hanya bagi masyarakat pada umumnya maupun pengusaha, tetapi juga kalangan akademisi khususnya. Kemungkinan untuk pengembangan dan pembangunan ekonomi nasional, peluangnya terbuka, terutama dengan data demografi penduduk yang mayoritas Islam. Berdasarkan keadaan tersebut, masyarakat akademis melakukan kajiankajian dari berbagai aspek, khususnya aspek ekonomi dan aspek hukum. Untuk aspek ekonomi, misalnya, dimuatnya mata kuliah dalam kurikulum dan bahkan dibukanya program studi khusus ekonomi Syariah. Sedangkan dari aspek hukum, yakni dengan dilakukannya diskusi, seminar dan workshop. Kegiatankegiatan tersebut merupakan media komunikasi antara teori dengan praktik yang bertujuan memformulasikan konsep-konsep hukum praksis, antara lain yang berkaitan dengan bagaimana memformulasikan akad sebagai konsep hukum praksis bagi kegiatan perbankan yang operasionalisasinya berbeda dengan bank konvensional. Pada fase ini, yang banyak digulirkan adalah fatwa dari DSN-MUI. Fatwa-fatwa dimaksud dan sebagaimana disebutkan sebelumnya terkategori sebagai konsep hukum, yakni berupa formulasi kebijaksanaan hukum yang ditetapkan oleh suatu masyarakat dalam hal ini DSN-MUI. Substansi fatwa yang diformulasikan berupaya merefleksikan budaya hukum, nilai hukum yang dianut oleh mayoritas penduduk Indonesia, dalam hal ini Islam. Upaya dimaksud, antara lain berelasi dengan proses pembentukan, penerapan, pengembangan, dan pembangunan hukum yang hendak dilaksanakannya.

Konsep hukum sebagaimana dijelaskan di atas, kemudian mengalami proses pembentukan dari yang semula tidak ada menjadi ada. Proses pembentukan ini menghasilkan suatu bentuk hukum berupa legislasi yang khusus mengatur perbankan Syariah, yakni UUPS 2008. Proses pembentukan hingga melahirkan bentuknya sebagai undang-undang mengacu pada UU Nomor 10 Tahun 2004, (sekarang diganti dengan UU Nomor 12 Tahun 2011) tentang pembentukan perundangundangan. Apabila dicermati konfigurasi substansinya, di dalamnya telah di atur perihal jenis dan kegiatan usaha serta jenis akad dari masingmasing kegiatan usaha. Sebagaimana telah disebutkan di awal, sekurangkurangnya terdapat 6 (enam) jenis akad sesuai dengan kegiatan usahanya. Akadakad dimaksud mengacu pada fatwa DSN-MUI mengalami perkembangan sejak tahun 2000 sampai dengan tahun 2017. Diaturnya akad-akad kegiatan usaha perbankan Syariah dalam pasalpasal UUPS 2008 merupakan langkah positivisasi hukum Islam normatif 
menjadi hukum Islam positif. Simultan dengan itu, terjadi proses transformasi hukum perikatan Islam ke dalam UUPS 2008.

Penerapan hukum UUPS 2008 pada umumnya akan berkaitan dengan lembaga, aparatur, sarana, dan prosedur-prosedur penerapan hukum. Khusus mengenai akad, dalam bentuknya yang notaril, maka penerapan hukumnya dilakukan oleh notaris, sehingga notaris pada saat menyusun akad-akad perbankan Syariah seyogyanya menerapkan ketentuan akad-akad perbankan Syariah sebagaimana diatur dalam UUPS 2008, serta memedomani fatwa-fatwa DSNMUI. Namun demikian, pada tahapan evaluasi hukum, khususnya kepatuhan terhadap ketentuan-ketentuan Syariah, masih belum dipenuhi sebagaimana yang diharapkan. Atas keadaan demikian, Bank Indonesia mengeluarkan Kodifikasi Peraturan Bank Indonesia tentang Pelaksanaan Prinsip Syariah dalam Kegiatan Penghimpunan dan Penyaluran Dana serta Pelayanan Jasa Bank Syariah, Produk Bank Syariah dan Unit Usaha Syariah, serta pedoman penyusunan akad-akad perbankan Syariah yang berisikan contoh-contoh akad produk perbankan Syariah yang disusun oleh Lembaga Pengembangan Perbankan Indonesia (LPPI).

\section{SIMPULAN}

Akad perbankan Syariah mempunyai karakteristik khusus berkaitan dengan pemenuhan prinsip Syariah, rukun dan syarat, serta menghindari riba, maisir, gharar, dan zhalim. Berdasarkan komponen teori transformasi sistem cybernetics paradigma hukum, transformasi akad perbankan Syariah ke dalam hukum perikatan nasional berada pada komponen konsep hukum dalam bentuk fatwa DSN-MUI tentang akad perbankan Syariah, UUPS 2008 Bab I Ketentuan Umum Pasal 1 angka 13, Peraturan Mahkamah Agung No. 2 Tahun 2008 tentang Kompilasi Hukum Ekonomi Syariah Buku II Bab III Pasal 22, Pasal 23, Pasal 24 dan Pasal 25, serta Kodifikasi Peraturan Bank Indonesia tentang Pelaksanaan Prinsip Syariah dalam Kegiatan Penghimpunan dan Penyaluran Dana serta Pelayanan Jasa Bank Syariah, Produk Bank Syariah dan Unit Usaha Syariah, serta pedoman penyusunan akad-akad perbankan Syariah yang berisikan contoh-contoh akad produk perbankan Syariah yang dikeluarkan oleh Lembaga Pengembangan Perbankan Indonesia (LPPI).

\section{DAFTAR PUSTAKA}

Devita, Irma. Kiat-kiat Cerdas, Mudah, dan Bijak Memahami Masalah Akad Syariah. Bandung: Mizan Pustaka, 2011.

Dewi, Gemala, Wirdyaningsih, dan Yeni Salma Barlianti. Hukum Perikatan Islam di Indonesia. Jakarta: Badan Penerbit FH UI, 2007. 
Djamil, Faturrahman. Penerapan Hukum Perjanjian dalam Transaksi di Lembaga Keuangan Syariah. Jakarta: Sinar Grafika, 2012.

Grassa, Rihab, dan Kaouthar Gazdar. "Law and Islamic Finance: How Legal Origins Affect Islamic Finance Development?" Borsa Istanbul Review 14, No. 3 (September 2014): 158-66. https://doi.org/10.1016/j. bir.2014.05.001.

Harun, Nasrun. Figh Muamalah. Jakarta: Gaya Media Pratama, 2011.

Nurhasanah, Neneng. "Optimalisasi Peran Dewan Pengawas Syariah (DPS) di Lembaga Keuangan Syariah." Jurnal Syiar Hukum Vol. XIII, No. 3 (November 2011).

Peraturan Mahkamah Agung tentang Kompilasi Hukum Ekonomi Syariah, Pub. L. No. Peraturan Mahkamah Agung RI Nomor 2 Tahun 2008 (t.t.).

Rahmawati. "Dinamika Akad Dalam Transaksi Ekonomi Syariah." Jurnal Al Iqtishad Vol. III No. 1 (Januari 2019).

Rasjidi, Lili, dan Ida Bagus Wyasa Putra. Hukum Sebagai Sistem. Jakarta: Fikahati Aneska, 2012.

Riadi, M. Erfan. "Kedudukan Fatwa Ditinjau Dari Hukum Islam dan Hukum Positif (Analisis Yuridis
Normatif)." Jurnal Ulumuddin Volume VI Tahun IV (Juni 2010).

Rozali, Asep. "Configuration of Act Number 21 of 2008 Based on Act Number 21 of 2011 and Qaidah Fiqh," 123-32. Universitas Mulawarman, Samarinda: Publishing Agency Faculty of Law, Indonesia University, 4 - 6 September.

Rozalinda. Fikih Ekonomi Syariah. Jakarta: Radja Grafindo, 2016.

Santoso, dan Suhadi. "Periodesasi Perkembangan Hukum Perbankan Syariah di Indonesia." Jurnal YUDISIA Vol. 6. No. 1 (2015).

Shiddiqie, Hasbi al. Pengantar Fikih Muamalah. Jakarta: Bulan Bintang, 1990.

Suhendi, Hendi. Fikih Muamalah. Jakarta: Raja Grafindo, 2008.

Susanto, Burhanuddin. "Tingkat Penggunaan Multi Akad Dalam Fatwa Dewan Syariah NasionalMajelis Ulama Indonesia." Jurnal al ahkam Volume 11, No. 1 (Juni 2016).

Usanti, Trisandini Prasastinah. "Akad Baku Pada Pembiayaan Murabahah di Bank Syariah." Jurnal Perspektif Volume XIII, No. 1 (Januari 2013).

Utama, Andrew Shandy. "Sejarah dan Perkembangan Regulasi Mengenai 
Perbankan Syariah Dalam Sistem Hukum Nasional." Jurnal Wawasan Yuridika Vol. 2 Nomor 2 (September 2018). 